NASA/TM-2000-209891, Vol. 198

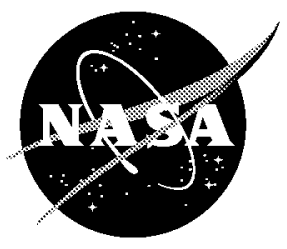

Technical Report Series on the Boreal Ecosystem-Atmosphere Study (BOREAS)

Forrest G. Hall and Sara Conrad, Editors

\title{
Volume 198
}

BOREAS TF-4 $\mathrm{CO}_{2}$ and $\mathrm{CH}_{4}$ Chamber Flux Data from the SSA

Dean Anderson, Robert Striegl and Kimberly Wickland U.S. Geological Survey, Denver

National Aeronautics and Space Administration

Goddard Space Flight Center

Greenbelt, Maryland 20771 
The NASA STI Program Office ... in Profile

Since its founding, NASA has been dedicated to the advancement of aeronautics and space science. The NASA Scientific and Technical Information (STI) Program Office plays a key part in helping NASA maintain this important role.

The NASA STI Program Office is operated by Langley Research Center, the lead center for NASA's scientific and technical information. The NASA STI Program Office provides access to the NASA STI Database, the largest collection of aeronautical and space science STI in the world. The Program Office is also NASA's institutional mechanism for disseminating the results of its research and development activities. These results are published by NASA in the NASA STI Report Series, which includes the following report types:

- TECHNICAL PUBLICATION. Reports of completed research or a major significant phase of research that present the results of NASA programs and include extensive data or theoretical analysis. Includes compilations of significant scientific and technical data and information deemed to be of continuing reference value. NASA's counterpart of peer-reviewed formal professional papers but has less stringent limitations on manuscript length and extent of graphic presentations.

- TECHNICAL MEMORANDUM. Scientific and technical findings that are preliminary or of specialized interest, e.g., quick release reports, working papers, and bibliographies that contain minimal annotation. Does not contain extensive analysis.

- CONTRACTOR REPORT. Scientific and technical findings by NASA-sponsored contractors and grantees.
- CONFERENCE PUBLICATION. Collected papers from scientific and technical conferences, symposia, seminars, or other meetings sponsored or cosponsored by NASA.

- SPECIAL PUBLICATION. Scientific, technical, or historical information from NASA programs, projects, and mission, often concerned with subjects having substantial public interest.

- TECHNICAL TRANSLATION. English-language translations of foreign scientific and technical material pertinent to NASA's mission.

Specialized services that complement the STI Program Office's diverse offerings include creating custom thesauri, building customized databases, organizing and publishing research results ... even providing videos.

For more information about the NASA STI Program Office, see the following:

- Access the NASA STI Program Home Page at http://www.sti.nasa.gov/STI-homepage.html

- E-mail your question via the Internet to help@sti.nasa.gov

- Fax your question to the NASA Access Help Desk at (301) 621-0134

- Telephone the NASA Access Help Desk at (301) 621-0390

- Write to:

NASA Access Help Desk

NASA Center for AeroSpace Information 7121 Standard Drive Hanover, MD 21076-1320 
NASA/TM-2000-209891, Vol. 198

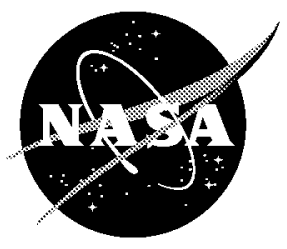

Technical Report Series on the Boreal Ecosystem-Atmosphere Study (BOREAS)

Forrest G. Hall and Sara Conrad, Editors

\section{Volume 198}

BOREAS TF-4 $\mathrm{CO}_{2}$ and $\mathrm{CH}_{4}$ Chamber Flux Data from the SSA

Dean Anderson, Robert Striegl and Kimberly Wickland U.S. Geological Survey, Denver

National Aeronautics and Space Administration

Goddard Space Flight Center

Greenbelt, Maryland 20771 


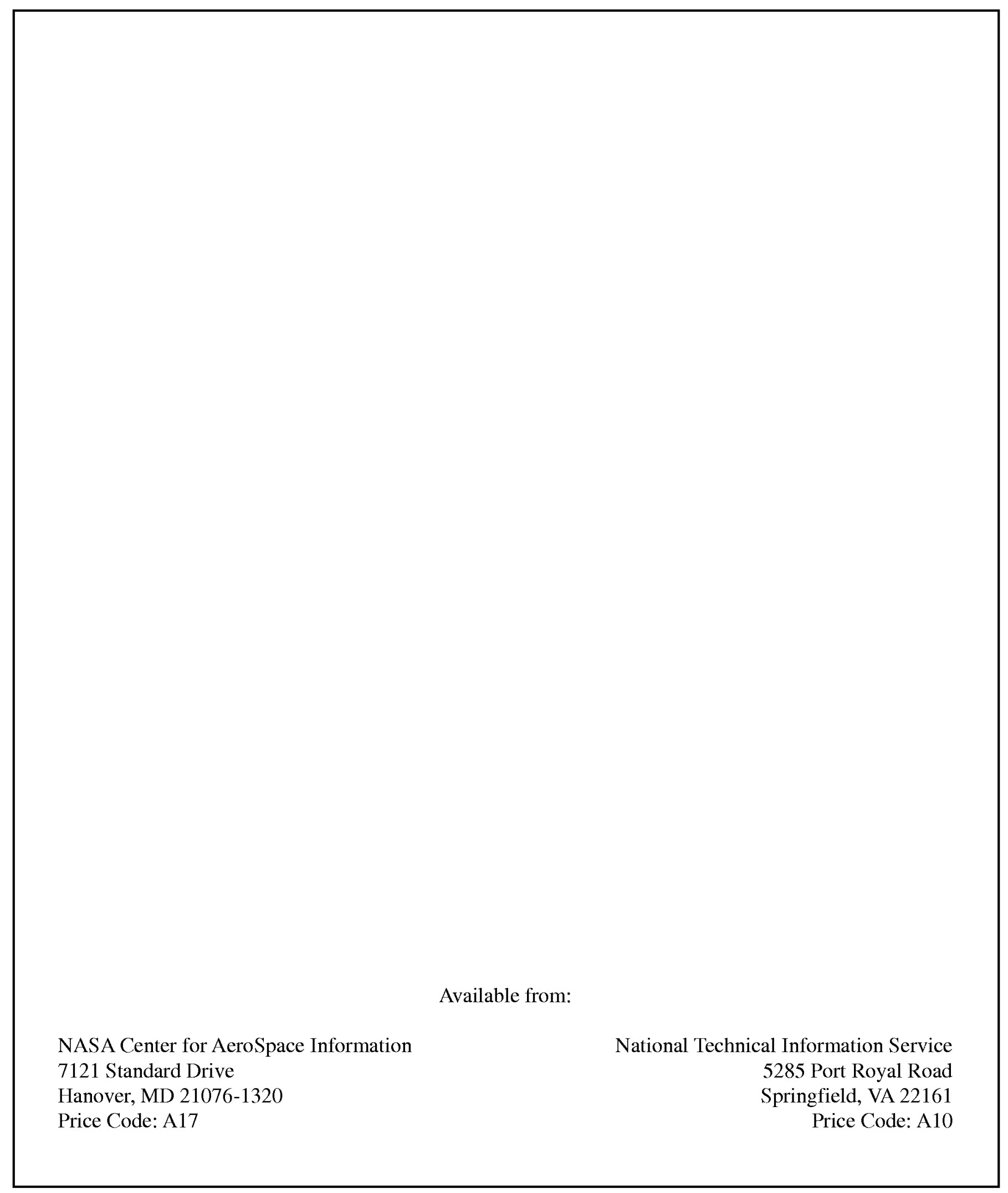




\title{
BOREAS TF-4 $\mathrm{CO}_{2}$ and $\mathrm{CH}_{4}$ Chamber Flux Data from the SSA
}

\author{
Dean Anderson, Robert Striegl, Kimberly Wickland
}

\section{Summary}

The BOREAS TF-4 team measured fluxes of $\mathrm{CO}_{2}$ and $\mathrm{CH}_{4}$ across the soil-air interface in four ages of jack pine forest at the BOREAS SSA during August 1993 to March 1995. Gross and net flux of $\mathrm{CO}_{2}$ and flux of $\mathrm{CH}_{4}$ between soil and air are presented for 24 chamber sites in mature jack pine forest, 20-year-old, 4-year-old, and clear cut areas. The data are stored in tabular ASCII files.

\section{Table of Contents}

1) Data Set Overview

2) Investigator(s)

3) Theory of Measurements

4) Equipment

5) Data Acquisition Methods

6) Observations

7) Data Description

8) Data Organization

9) Data Manipulations

10) Errors

11) Notes

12) Application of the Data Set

13) Future Modifications and Plans

14) Software

15) Data Access

16) Output Products and Availability

17) References

18) Glossary of Terms

19) List of Acronyms

20) Document Information

\section{Data Set Overview}

\subsection{Data Set Identification}

BOREAS TF-04 $\mathrm{CO}_{2}$ and $\mathrm{CH}_{4}$ Chamber Flux Data from the SSA

\subsection{Data Set Introduction}

Data presented in this document were collected at the Old Jack Pine (OJP) and Young Jack Pine (YJP) tower flux sites and nearby clear cut areas at the BOReal Ecosystem-Atmosphere Study (BOREAS) Southern Study Area (SSA). The BOREAS Tower Flux (TF)-04 team measured fluxes of carbon dioxide $\left(\mathrm{CO}_{2}\right)$ and methane $\left(\mathrm{CH}_{4}\right)$ across the soil-air interface in four ages of jack pine forest at the SSA during August 1993 to March 1995. Gross and net flux of $\mathrm{CO}_{2}$ and flux of $\mathrm{CH}_{4}$ between soil and air are presented for 24 chamber sites in mature jack pine forest, 20-year-old and 4-year-old stands, and a clear cut area. The data are stored in tabular American Standard Code for Information Interchange (ASCII) files. 


\subsection{Objective/Purpose}

This study presents data relevant to understanding the transfer and storage of carbon among soil, the unsaturated zone, ground cover vegetation, and understory air in jack pine forest at the SSA. The data were collected continuously from May through September 1994 and during March 1995.

\subsection{Summary of Parameters}

The primary focus is on the net fluxes of $\mathrm{CO}_{2}$ and $\mathrm{CH}_{4}$ measured.

\subsection{Discussion}

Jack pine woodlands are an important component of the boreal forest, covering more than $2 \times 10^{12}$ $\mathrm{m}^{2}$ of predominantly well-drained uplands in northern North America. As part of BOREAS, our study objectives were (1) to compare soil respiration at an undisturbed 65- to 90-year-old mature jack pine-lichen woodland with soil respiration at a formerly continuous portion of the stand that was clear-cut harvested during the previous winter, and (2) to identify and quantify the sources of $\mathrm{CO}_{2}$ and $\mathrm{CH}_{4}$ production within the soil profile.

\subsection{Related Data Sets}

BOREAS TGB-01 NSA CH4 and CO2 Chamber Flux Data

BOREAS TGB-01 CH4 Concentration and Flux Data from NSA Tower Sites

BOREAS TGB-01 NSA SF6 Chamber Flux Data

BOREAS TGB-01/TGB-03 CH4 Chamber Flux Data over the NSA Fen

BOREAS TGB-01/TGB-03 NEE Data over the NSA Fen

BOREAS TGB-03 Plant Species Composition Data over the NSA Fen

BOREAS TGB-03 CH4 and CO2 Chamber Flux Data over NSA Upland Sites

BOREAS TF-04 CO2 and CH4 Soil Profile Data from the SSA

\section{Investigator(s)}

\subsection{Investigator(s) Name and Title}

Dr. Rob Striegl, Hydrologist

United States Geological Survey

Dr. Kimberly Wickland

United States Geological Survey

\subsection{Title of Investigation}

Automated Measurements of $\mathrm{CO}_{2}$ Exchange at the Moss Surface of a Black Spruce Forest

\subsection{Contact Information}

\section{Contact 1:}

Dr. Rob Striegl

Hydrologist, United States Geological Survey

P.O. Box 25046 MS 413

Denver, CO 80225

rstriegl@usgs.gov

\section{Contact 2:}

Dr. Kimberly P. Wickland

Hydrologist, United States Geological Survey

P.O. Box 25046 MS 413

Denver, CO 80225 


\section{Contact 3:}

Jeffrey A. Newcomer

Raytheon ITSS

Code 923

NASA GSFC

Greenbelt, MD 20771

(301) 286-7858

(301) 286-0239 (fax)

Jeffrey.Newcomer@gsfc.nasa.gov

\section{Theory of Measurements}

Atmospheric chemistry measurements and modeling studies identify a global imbalance between known $\mathrm{CO}_{2}$ production and uptake, with a potentially large terrestrial carbon sink possible in boreal forests. Northern woodlands are also perceived to be very sensitive to climate change. The predicted warming and drying of the boreal region could profoundly affect regional carbon sources and sinks. Carbon cycling of the boreal forest has consequently been a central theme of much recent field research. With the intent of eventually extrapolating land-based carbon, energy, and water flux measurements to the entire boreal forest biome, BOREAS subdivided the northern and southern sections of Canadian boreal forest into aspen, jack pine, and bog-fen landscapes for intensive study. Studies within these vegetation types focused on a variety of factors that influence carbon cycling, including forest stand age and land surface disturbances (Sellers et al., 1995).

Soil respiration, the second largest flux in the global carbon cycle, includes all $\mathrm{CO}_{2}$ produced by roots, soil organisms, and oxidation that is emitted across the soil-air interface. Although globally important, soil respiration is not well characterized spatially or seasonally for most ecosystems.

We derived response curves of measured soil $\mathrm{CO}_{2}$ emission versus soil temperature for the measurement transects and applied them to soil temperatures that were continuously recorded at the BOREAS OJP flux tower, located approximately $0.2 \mathrm{k}$, northwest of the OJP transect. This allowed for simulation of continuous soil $\mathrm{CO}_{2}$ emissions for May-September 1994. The simulation results, when considered with the winter tree removal, the deep well-sorted sandy soil, and the lack of complexity of the plant and soil communities, permitted separation of surface-soil, deep-soil, and tree-root respiration at the OJP stand. The OJP fluxes quantify the amount of $\mathrm{CO}_{2}$ that is transported across the forest floor and is available for photosynthetic uptake by ground cover and understory plants and tress or for emission to the atmosphere. Because the groundcover was destroyed and all trees were removed by clear-cutting, the " $\mathrm{CC}$ " site fluxes represent net $\mathrm{CO}_{2}$ emission to the atmosphere during the period between forest harvest and re-establishment of plant cover.

\section{Equipment}

\subsection{Sensor/Instrument Description}

\subsubsection{Collection Environment}

Data were collected under all environmental conditions.

\subsubsection{Source/Platform}

Ground.

\subsubsection{Source/Platform Mission Objectives}

Support investigators and chambers. 


\subsubsection{Key Variables}

$\mathrm{CO}_{2}$ and $\mathrm{CH}_{4}$ flux.

\subsubsection{Principles of Operation}

$\mathrm{CO}_{2}$ and $\mathrm{CH}_{4}$ fluxes were measured by the static chamber technique, which involves measuring the accumulation or loss of gas concentration within chambers placed on the soil surface versus time. The chambers, which are cylindrical with an open bottom and a closed top, are constructed from $0.30-\mathrm{m}$ inside diameter polyvinylchloride (PVC) irrigation pipe. To prevent gas leakage to or from the chambers during measurement, they were affixed by a gasket to a collar, constructed from the same pipe material, that was inserted permanently into the soil to a depth of $0.10 \mathrm{~m}$. When deployed, the collars and chambers had a combined height of 0.28 to $0.30 \mathrm{~m}$. The chambers have a coiled $1.6-\mathrm{mm}$ inside diameter aluminum tube installed through the sidewall near the top to equalize inside and outside pressure and are fitted with various gas ports for air circulation and sample collection. Gross soil $\mathrm{CO}_{2}$ flux is the total amount of $\mathrm{CO}_{2}$ that passes across the soil-groundcover/air interface in the absence of photosynthesis. Chambers for measurement of gross $\mathrm{CO}_{2}$ flux and $\mathrm{CH}_{4}$ flux have opaque PVC tops that create a dark chamber environment. Net soil $\mathrm{CO}_{2}$ flux is gross flux minus $\mathrm{CO}_{2}$ uptake by groundcover photosynthesis. Chambers for measurement of net $\mathrm{CO}_{2}$ flux have clear polycarbonate tops that are optically transparent across the window of photosynthetically active radiation, allowing plant photosynthesis to occur. Air is recirculated inside the chambers at a rate of 0.25 chamber volume per minute to ensure mixing.

Gross and net $\mathrm{CO}_{2}$ flux were measured by continuously monitoring the $\mathrm{CO}_{2}$ concentration in air circulating in a chamber placed on the soil surface. $\mathrm{CO}_{2}$ concentrations were recorded at 20 -second intervals for 8 minutes using a LI-COR 6200 infrared gas analyzer (IRGA).

Soil $\mathrm{CH}_{4}$ flux was measured by gas chromatograph (GC) analysis of a time series of six syringe samples of air collected from the center of volume of the chamber. Deployment times ranged from 24 to 40 minutes, depending on the anticipated flux rate. Rate of gas emission of consumption were determined by the equation:

$$
\mathrm{J}=\mathrm{dC} / \mathrm{dt} \times \mathrm{h}
$$

where $J$ is the rate of gas flux across the soil surface $\left(\mathrm{mol} / \mathrm{m}^{2} / \mathrm{s}\right) \mathrm{C}$ is the gas concentration in the chamber at ambient temperature and pressure $\left(\mathrm{mol} / \mathrm{m}^{3}\right), \mathrm{t}$ is time, $\mathrm{h}$ is chamber height $(\mathrm{m})$, and $\mathrm{dC} / \mathrm{dt}$ is the slope of the best fit of the time series of concentration in the chamber as time approaches zero.

\subsubsection{Sensor/Instrument Measurement Geometry}

Not applicable.

\subsubsection{Manufacturer of Sensor/Instrument}

The chambers, which are cylindrical with an open bottom and a closed top, are constructed from $0.30 \mathrm{~m}$ inside diameter polyvinylchloride (PVC) irrigation pipe. To prevent gas leakage to or from the chambers during measurement, that were affixed by a gasket to a collar, constructed from the same pipe material, that was inserted permanently into the soil to a depth of $0.10 \mathrm{~m}$. When deployed, the collars and chambers had a combined height of 0.28 to $0.30 \mathrm{~m}$. The chambers have a coiled $1.6-\mathrm{mm}$ inside diameter aluminum tube installed through the sidewall near the top to equalize inside and outside pressure and are fitted with various gas ports for air circulation and sample collection.

IRGA, Model 6262

LI-COR, Inc.

Lincoln, NE 


\subsection{Calibration}

\subsubsection{Specifications}

None given.

\subsubsection{Tolerance}

None given.

\subsubsection{Frequency of Calibration}

Traceable gas calibration standards for all $\mathrm{CO}_{2}$ and $\mathrm{CH}_{4}$ analyses were provided by the BOREAS project.

\subsubsection{Other Calibration Information \\ None given.}

\section{Data Acquisition Methods}

Soil respiration was measured using closed chambers that attached to chamber collars permanently installed in the soil. Three pairs of the $0.38 \mathrm{~m}$ diameter chamber collars were inserted $0.10 \mathrm{~m}$ into the soil at each site along a $60-\mathrm{m}$ transect, having $30 \mathrm{~m}$ between pairs of collars and $1 \mathrm{~m}$ between collars within pairs.

Traceable gas calibration standards for all $\mathrm{CO}_{2}$ and $\mathrm{CH}_{4}$ analyses were provided by BOREAS operations. $\mathrm{CO}_{2}$ concentrations were measured using nondispersive IRGAs calibrated to span the expected concentration range. Three different IRGAs were used for measuring $\mathrm{CO}_{2}$ concentration at the jack pine soil gas transects. Accumulation of $\mathrm{CO}_{2}$ in soil gas flux chambers was measured using LI-COR model 6200. In situ soil $\mathrm{CO}_{2}$ concentrations exceed the range of the LI-COR 6200, so two PP System model EGM IRGAs were used, one having a range up to 5000 parts per million (ppm) $\mathrm{CO}_{2}$

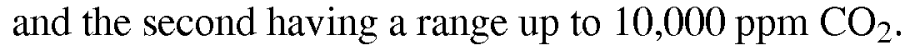

$\mathrm{CH}_{4}$ concentrations were measured using a Chrompack model 438A GC having a 2-meter 80-100 mesh Porapak-N column and a flame ionization detector. Carrier gas was nitrogen and the oven temperature was maintained at $38^{\circ} \mathrm{C}$. $\mathrm{CH}_{4}$ concentrations were calculated from standards curves established from a series of $\mathrm{CH}_{4}$ Standards run between every 8 to 10 samples. Concentrations smaller than $0.49 \mathrm{ppm}$ were calculated by linear extrapolation of integrator response between a $0.49 \mathrm{ppm}^{\mathrm{CH}_{4}}$ standard and a nitrogen blank.

The measurements were made by sealing a 0.30 -m tall opaque polyvinyl chloride chamber cover over a chamber collar and continuously circulating air from the chamber at top center, through a LI-COR $6200 \mathrm{CO}_{2}$ analyzer, and back into the chamber through a perforated air-dispersion ring on the inside of the chamber base. Chamber $\mathrm{CO}_{2}$ concentrations were measured at 1-s intervals and mean concentrations were recorded at 15 -s intervals for 8 minutes. Insertion of the chamber collars into the soil, circulation of chamber air through the gas analyzer, the relatively large chamber diameter, and the relatively short chamber deployment times were all intended to minimize chamber effects known to influence soil gas flux measurements. $\mathrm{CO}_{2}$ emission rates were calculated using:

$$
\mathrm{J}=\mathrm{dC} / \mathrm{dt} \times \mathrm{h}
$$

where $\mathrm{J}$ is the rate of $\mathrm{CO}_{2}$ flux across the soil surface $\left(\mathrm{mol} /\left(\mathrm{m}^{2} \mathrm{~s}\right)\right), \mathrm{C}$ is the $\mathrm{CO}_{2}$ concentration in the chamber at ambient temperature and pressure $\left(\mathrm{mol} / \mathrm{m}^{3}\right), \mathrm{t}$ is time, $\mathrm{h}$ is chamber height $(\mathrm{m})$, and $\mathrm{dC} / \mathrm{dt}$ is the slope of the best fit of the time series of $\mathrm{CO}_{2}$ concentration in the chamber as time approaches zero. 


\section{Observations}

\subsection{Data Notes}

None given.

\subsection{Field Notes}

None given.

\section{Data Description}

\subsection{Spatial Characteristics}

\subsubsection{Spatial Coverage}

The North American Datum of 1983 (NAD83) coordinates of the sites are:

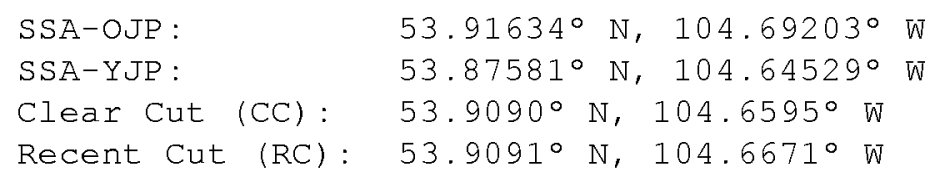

\subsubsection{Spatial Coverage Map}

Not available.

\subsubsection{Spatial Resolution}

These are point measurements made at the given locations.

\subsubsection{Projection}

Not applicable.

\subsubsection{Grid Description}

Not applicable.

\subsection{Temporal Characteristics}

\subsubsection{Temporal Coverage}

The data set covers the period from 26-May-1994 to 21-Mar-1995.

\subsubsection{Temporal Coverage Map}

Not available.

\subsubsection{Temporal Resolution}

Gross and net $\mathrm{CO}_{2}$ flux were measured by continuously monitoring the $\mathrm{CO}_{2}$ concentration in air circulating in a chamber placed on the soil surface. $\mathrm{CO}_{2}$ concentrations were recorded at 20 -second intervals for 8 minutes using a LI-COR 6200 IRGA.

Soil $\mathrm{CH}_{4}$ flux was measured by GC analysis of a time series of six syringe samples of air collected from the center of volume of the chamber. Deployment times ranged from 24 to 40 minutes, depending on the anticipated flux rate. 


\subsection{Data Characteristics}

\subsubsection{Parameter/Variable}

The parameters contained in the data files on the CD-ROM are:

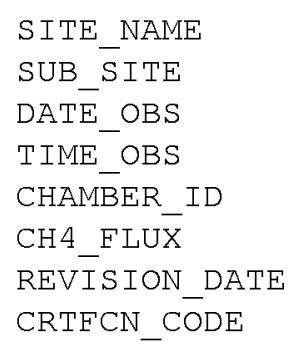

\subsubsection{Variable Description/Definition}

The descriptions of the parameters contained in the data files on the CD-ROM are:

TFO4_CH4_CHAMBER_FLUX :

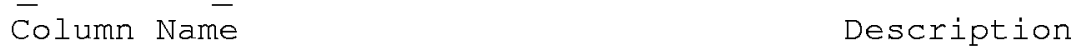


SUB_SITE

DATE OBS

TIME_OBS

CHAMBER ID

CH4_FLUX

REVISION DATE

CRTFCN_CODE
The identifier assigned to the sub-site by BOREAS in the format GGGGG-IIIII, where GGGGG is the group associated with the sub-site instrument, e.g. HYD06 or STAFF, and IIIII is the identifier for sub-site, often this will refer to an instrument.

The date on which the data were collected.

The Greenwich Mean Time (GMT) when the data were collected.

Identifier assigned to the chamber measured Methane flux.

The most recent date when the information in the referenced data base table record was revised. The BOREAs certification level of the data. Exa Examples are CPI (Checked by PI), CGR (Certified by Group), PRE (Preliminary), and CPI-??? (CPI but questionable).

TF04 GROSS CO2 CHAMBER FLUX :

Column Name

SITE_NAME

SUB_SITE

DATE_OBS

TIME_OBS

CHAMBER_ID

GROSS_CO2_FLUX

REVISION DATE

CRTFCN_CODE
Description

The identifier assigned to the site by BOREAS, in the format SSS-TTT-CCCCC, where SSS identifies the portion of the study area: NSA, SSA, REG, TRN, and TTT identifies the cover type for the site, 999 if unknown, and CCCCC is the identifier for site, exactly what it means will vary with site type.

The identifier assigned to the sub-site by BOREAS in the format GGGGG-IIIII, where GGGGG is the group associated with the sub-site instrument, e.g. HYD06 or STAFF, and IIIII is the identifier for sub-site, often this will refer to an instrument.

The date on which the data were collected. The Greenwich Mean Time (GMT) when the data were collected.

Identifier assigned to the chamber measured The gross $\mathrm{CO} 2$ flux measured within the chamber. The most recent date when the information in the referenced data base table record was revised. The BOREAS certification level of the data. Exa Examples are CPI (Checked by PI), CGR (Certified by Group), PRE (Preliminary), and CPI-??? (CPI but questionable). 
TFO4_NET_CO2_CHAMBER_F LUX :

Column Name

SITE_NAME

SUB_SITE

DATE_OBS

TIME_OBS

CHAMBER_ID

NET_CO2_FLUX

REVISION_DATE

CRTFCN_CODE
Description

The identifier assigned to the site by BOREAS, in the format SSS-TTT-CCCCC, where SSS identifies the portion of the study area: NSA, SSA, REG, TRN, and TTT identifies the cover type for the site, 999 if unknown, and CCCCC is the identifier for site, exactly what it means will vary with site type.

The identifier assigned to the sub-site by BOREAS in the format GGGGG-IIIII, where GGGGG is the group associated with the sub-site instrument, e.g. HYD06 or STAFF, and IIIII is the identifier for sub-site, often this will refer to an instrument.

The date on which the data were collected.

The Greenwich Mean Time (GMT) when the data were collected.

Identifier assigned to the chamber measured The net $\mathrm{CO} 2$ flux measured within the chamber. The most recent date when the information in the referenced data base table record was revised. The BOREAS certification level of the data. Exa Examples are CPI (Checked by PI), CGR (Certified by Group), PRE (Preliminary), and CPI-??? (CPI but questionable).

\subsubsection{Unit of Measurement}

The measurement units for the parameters contained in the data files on the CD-ROM are:

TF 04 _CH 4 _CHAMBER_FLUX :

Column Name

SITE_NAME
SUB_SITE
DATE_OBS
TIME_OBS
CHAMBER_ID
CH4_FLUX
REVISION_DATE
CRTECN_CODE

Units

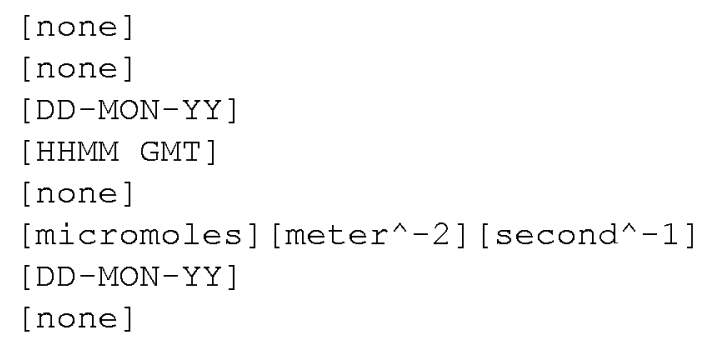

TFO4_GROSS_CO2_CHAMBER_FLUX :

Column Name

SITE_NAME
SUB_SITE
DATE_OBS
TIME_OBS
CHAMBER_ID
GROSS_CO2_FLUX
REVISION_DATE
CRTFCN_CODE

Units

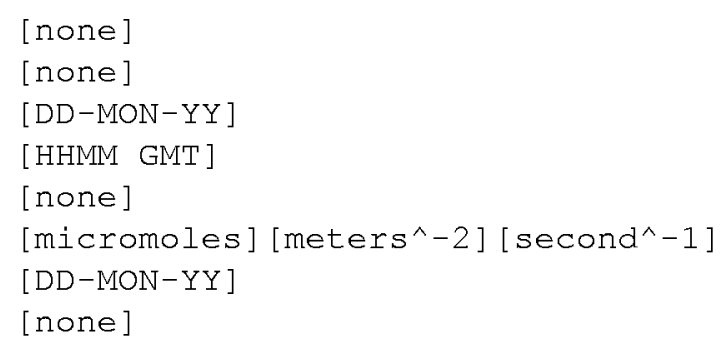


TFO4_NET_CO2_CHAMBER_FLUX:

Column Name

Units

SITE NAME

SUB SITE

[none]

DATE OBS

[none ]

TIME OBS

[DD-MON-YY]

[HHMM GMT]

CHAMBER ID

[none ]

NET CO2 FLUX

[micromoles] [meter ${ }^{\wedge}-2$ ] [ second ${ }^{\wedge}-1$ ]

REVISION DATE

[DD-MON-YY]

CRTFCN CODE

[none ]

\subsubsection{Data Source}

The source of the parameter values contained in the data files on the CD-ROM are:

TFO4_CH4_CHAMBER_FLUX :

Column Name Data Source

$\begin{array}{ll}\text { SITE_NAME } & \text { [Assigned by BORIS Staff] } \\ \text { SUB_SITE } & \text { [Assigned by BORIS Staff] } \\ \text { DATE_OBS } & \text { [ Investigator] } \\ \text { TIME_OBS } & \text { [ Investigator] } \\ \text { CHAMBER_ID } & \text { [ Investigator] } \\ \text { CH4_FLUX } & \text { [Gas Chromatograph] } \\ \text { REVISION_DATE } & \text { [Assigned by BORIS Staff] } \\ \text { CRTFCN_CODE } & \text { [Assigned by BORIS Staff] }\end{array}$

TF04_GROSS CO2 CHAMBER_FLUX :

Column Name Data Source

SITE NAME

SUB_SITE

DATE OBS

TIME OBS

CHAMBER ID

GROSS $\mathrm{CO} 2$ FLUX

REVISION DATE

CRTFCN CODE
[Assigned by BORIS Staff]

[Assigned by BORIS Staff]

[ Investigator]

[ Investigator]

[ Investigator]

[LI-COR 6200 CO2 analyzer]

[Assigned by BORIS Staff]

[Assigned by BORIS Staff]

TF 04 _NET_CO2_CHAMBER_FLUX :

Column Name

Data Source

SITE NAME

SUB SITE

DATE OBS

TIME OBS

CHAMBER ID

NET_CO2_FLUX

REVISION DATE

CRTFCN CODE

Data Source
[Assigned by BORIS Staff]
[Assigned by BORIS Staff]
[Investigator]
[Investigator]
[Investigator]
[II-CoR 6200 CO2 analyzer]
[Assigned by BORIS Staff]
[Assigned by BORIS Staff]


7.3.5 Data Range

The following table gives information about the parameter values found in the data files on the CD-ROM.

\begin{tabular}{|c|c|c|c|c|c|c|}
\hline \multicolumn{7}{|c|}{ Maximum } \\
\hline & Data & Data & Data & Data & Detect & Not \\
\hline Column Name & Value & Value & Value & Value & Limit & Cllcto \\
\hline \multicolumn{7}{|c|}{---------- - - - - - - - - - - - - - - - - - - - - - - - - - - - - - - - - - - - - - - - - - - - - - - - - - - - - - - - - - - } \\
\hline SITE_NAME & SSA-9JP-CLRCT & SSA-YJP-FLXTR & None & None & None & None \\
\hline SUB_SITE & 9TF04-FLX01 & $9 \mathrm{TF} 04-\mathrm{FLX02}$ & None & None & None & None \\
\hline DATE_OBS & $31-M A Y-94$ & $21-\mathrm{MAR}-95$ & None & None & None & None \\
\hline TIME_OBS & 1420 & 2341 & None & None & None & None \\
\hline CHAMBER_ID & A & $\mathrm{X}$ & None & None & None & None \\
\hline CH4_FLUX & -643 & 0 & None & None & None & None \\
\hline REVISION_DATE & $09-N O V-98$ & $10-N O V-98$ & None & None & None & None \\
\hline CRTFCN CODE & CPI & CPI & None & None & None & None \\
\hline
\end{tabular}

TF 04 _GROSS_CO2_CHAMBER_FLUX :

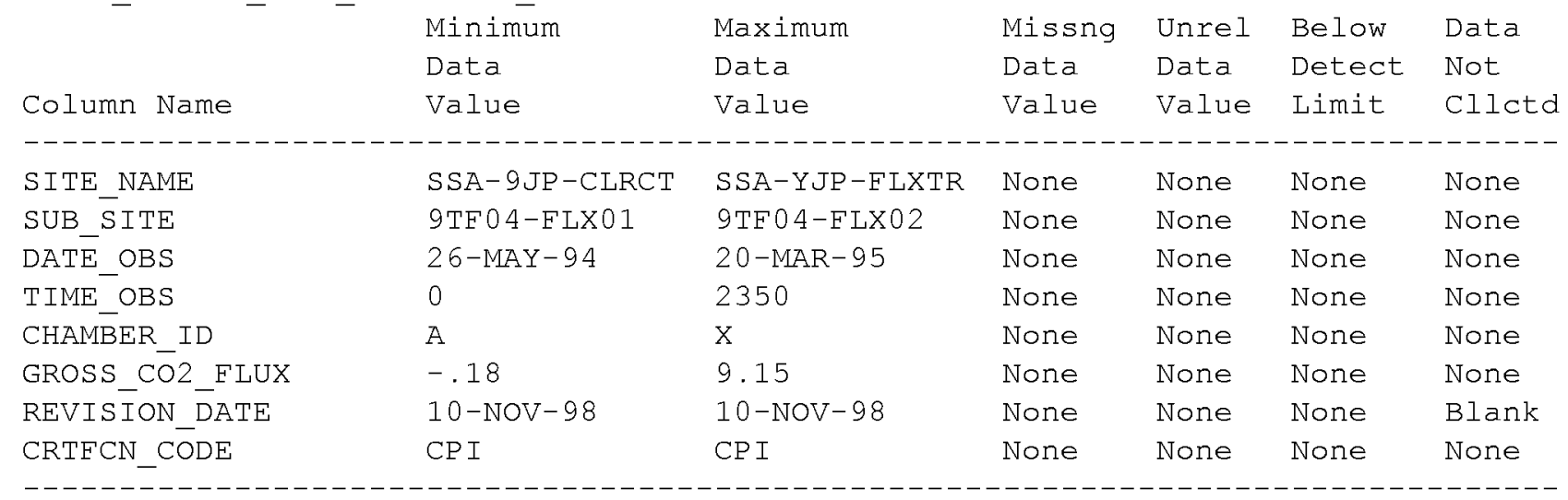

TF 04 NET_CO2_CHAMBER_FLUX :

\begin{tabular}{|c|c|c|c|c|c|c|}
\hline Column Name & $\begin{array}{l}\text { Minimum } \\
\text { Data } \\
\text { Value }\end{array}$ & $\begin{array}{l}\text { Maximum } \\
\text { Data } \\
\text { Value }\end{array}$ & $\begin{array}{l}\text { Missng } \\
\text { Data } \\
\text { Value }\end{array}$ & $\begin{array}{l}\text { Unrel } \\
\text { Data } \\
\text { Value }\end{array}$ & $\begin{array}{l}\text { Below } \\
\text { Detect } \\
\text { Limit }\end{array}$ & $\begin{array}{l}\text { Data } \\
\text { Not } \\
\text { Cllctd }\end{array}$ \\
\hline------------ & ---------- & -------------- & ------ & ------ & ------ & ------ \\
\hline SITE_NAME & SSA-9JP-CLRCT & SSA-YJP-FLXTR & None & None & None & None \\
\hline SUB_SITE & $9 \mathrm{TF} 04-\mathrm{ELX} 01$ & $9 \mathrm{TF} 04-\mathrm{FLX02}$ & None & None & None & None \\
\hline DATE_OBS & $02-J U N-94$ & $15-\mathrm{SEP}-94$ & None & None & None & None \\
\hline TIME_OBS & 234 & 2308 & None & None & None & None \\
\hline CHAMBER_ID & A & $\mathrm{X}$ & None & None & None & None \\
\hline NET_CO2_ELUX & -1.82 & 6.63 & None & None & None & None \\
\hline REVISION_DATE & $10-\mathrm{NOV}-98$ & $10-\mathrm{NOV}-98$ & None & None & None & None \\
\hline CRTFCN_CODE & $\mathrm{CPI}$ & $\mathrm{CPI}$ & None & None & None & None \\
\hline
\end{tabular}

Minimum Data Value -- The minimum value found in the column.

Maximum Data Value -- The maximum value found in the column.

Missng Data Value -- The value that indicates missing data. This is used to indicate that an attempt was made to determine the parameter value, but the attempt was unsuccessful.

Unrel Data Value -- The value that indicates unreliable data. This is used 
to indicate an attempt was made to determine the parameter value, but the value was deemed to be unreliable by the analysis personnel.

Below Detect Limit -- The value that indicates parameter values below the instruments detection limits. This is used to indicate that an attempt was made to determine the parameter value, but the analysis personnel determined that the parameter value was below the detection limit of the instrumentation.

Data Not Cllctd

-- This value indicates that no attempt was made to determine the parameter value. This usually indicates that BORIS combined several similar but not identical data sets into the same data base table but this particular science team did not measure that parameter.

Blank -- Indicates that blank spaces are used to denote that type of value. N/A - - Indicates that the value is not applicable to the respective column. None -- Indicates that no values of that sort were found in the column.

\subsection{Sample Data Record}

The following are wrapped versions of data record from a sample data file on the CD-ROM.

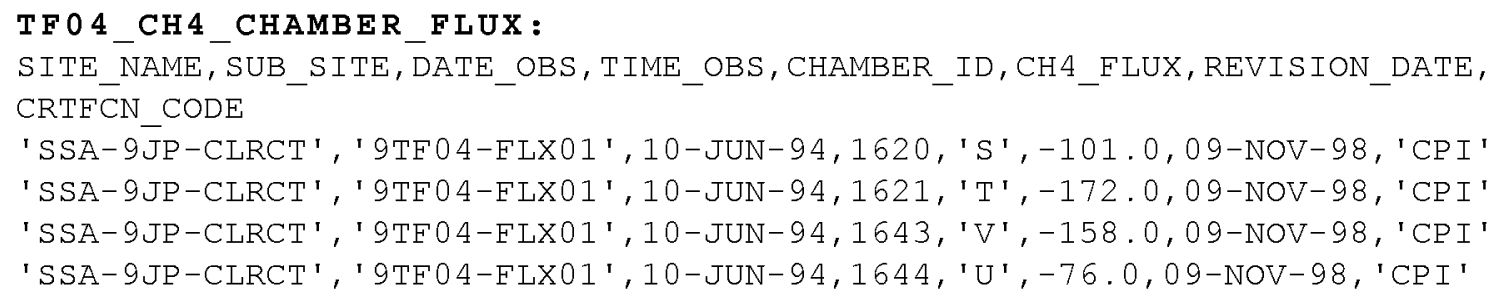




\section{Data Organization}

\subsection{Data Granularity}

The smallest unit of data tracked by the BOREAS Information System (BORIS) is the measurement(s) made for a given site at a given time.

\subsection{Data Format(s)}

The Compact Disk-Read-Only Memory (CD-ROM) files contain ASCII numerical and character fields of varying length separated by commas. The character fields are enclosed with single apostrophe marks. There are no spaces between the fields.

Each data file on the CD-ROM has four header lines of Hyper-Text Markup Language (HTML) code at the top. When viewed with a Web browser, this code displays header information (data set title, location, date, acknowledgments, etc.) and a series of HTML links to associated data files and related data sets. Line 5 of each data file is a list of the column names, and line 6 and following lines contain the actual data.

\section{Data Manipulations}

\subsection{Formulae}

\subsubsection{Derivation Techniques and Algorithms \\ None given.}

\subsection{Data Processing Sequence}

\subsubsection{Processing Steps}

None given

\subsubsection{Processing Changes}

None given.

\subsection{Calculations}

\subsubsection{Special Corrections/Adjustments}

None given.

\subsubsection{Calculated Variables}

$\mathrm{CO}_{2}$ emission rates were calculated using $\mathrm{J}=\mathrm{dC} / \mathrm{dt} \mathrm{x} \mathrm{h}$, where $\mathrm{J}$ is the rate of $\mathrm{CO}_{2}$ flux across the soil surface $\left(\mathrm{mol} /\left(\mathrm{m}^{2} \mathrm{~s}\right)\right), \mathrm{C}$ is the $\mathrm{CO}_{2}$ concentration in the chamber at ambient temperature and pressure $\left(\mathrm{mol} / \mathrm{m}^{3}\right), \mathrm{t}$ is time, $\mathrm{h}$ is chamber height $(\mathrm{m})$, and $\mathrm{dC} / \mathrm{dt}$ is the slope of the best fit of the time series of $\mathrm{CO}_{2}$ concentration in the chamber as time approaches zero.

\subsection{Graphs and Plots}

None given. 


\section{Errors}

10.1 Sources of Error

None given.

10.2 Quality Assessment

10.2.1 Data Validation by Source

None given.

10.2.2 Confidence Level/Accuracy Judgment

None given.

10.2.3 Measurement Error for Parameters

None given.

10.2.4 Additional Quality Assessments

None given.

10.2.5 Data Verification by Data Center

Data were examined for general consistency and clarity.

\section{Notes}

11.1 Limitations of the Data None given.

11.2 Known Problems with the Data None given.

11.3 Usage Guidance None given.

11.4 Other Relevant Information None given.

\section{Application of the Data Set}

None given.

\section{Future Modifications and Plans}

None given. 


\section{Software}

\subsection{Software Description}

None given.

\subsection{Software Access}

Not applicable.

\section{Data Access}

The $\mathrm{CO}_{2}$ and $\mathrm{CH}_{4}$ chamber flux data are available from the Earth Observing System Data and Information System (EOSDIS) Oak Ridge National Laboratory (ORNL) Distributed Active Archive Center (DAAC).

\subsection{Contact Information}

For BOREAS data and documentation please contact:

ORNL DAAC User Services

Oak Ridge National Laboratory

P.O. Box 2008 MS-6407

Oak Ridge, TN 37831-6407

Phone: (423) 241-3952

Fax: (423) 574-4665

E-mail: ornldaac@ornl.gov or ornl@eos.nasa.gov

\subsection{Data Center Identification}

Earth Observing System Data and Information System (EOSDIS) Oak Ridge National Laboratory (ORNL) Distributed Active Archive Center (DAAC) for Biogeochemical Dynamics http://www-eosdis.ornl.gov/.

\subsection{Procedures for Obtaining Data}

Users may obtain data directly through the ORNL DAAC online search and order system [http://www-eosdis.ornl.gov/] and the anonymous FTP site [ftp://www-eosdis.ornl.gov/data/] or by contacting User Services by electronic mail, telephone, fax, letter, or personal visit using the contact information in Section 15.1.

\subsection{Data Center Status/Plans}

The ORNL DAAC is the primary source for BOREAS field measurement, image, GIS, and hardcopy data products. The BOREAS CD-ROM and data referenced or listed in inventories on the CD-ROM are available from the ORNL DAAC.

\section{Output Products and Availability}

\subsection{Tape Products}

None.

\subsection{Film Products}

None.

\subsection{Other Products}

These data are available on the BOREAS CD-ROM series. 


\section{References}

\subsection{Platform/Sensor/Instrument/Data Processing Documentation}

None given.

\subsection{Journal Articles and Study Reports}

Newcomer, J., D. Landis, S. Conrad, S. Curd, K. Huemmrich, D. Knapp, A. Morrel1, J. Nickeson, A. Papagno, D. Rinker, R. Strub, T. Twine, F. Hall, and P. Sellers, eds. 2000. Collected Data of The Boreal Ecosystem-Atmosphere Study. NASA. CD-ROM.

Sellers, P. and F. Hall. 1994. Boreal Ecosystem-Atmosphere Study: Experiment Plan. Version 1994-3.0, NASA BOREAS Report (EXPLAN 94).

Sellers, P. and F. Hall. 1996. Boreal Ecosystem-Atmosphere Study: Experiment Plan. Version 1996-2.0, NASA BOREAS Report (EXPLAN 96).

Sellers, P., F. Hall, and K.F. Huemmrich. 1996. Boreal Ecosystem-Atmosphere Study: 1994 Operations. NASA BOREAS Report (OPS DOC 94).

Sellers, P., F. Hall, and K.F. Huemmrich. 1997. Boreal Ecosystem-Atmosphere Study: 1996 Operations. NASA BOREAS Report (OPS DOC 96).

Sellers, P., F. Hall, H. Margolis, B. Kelly, D. Baldocchi, G. den Hartog, J. Cihlar, M.G. Ryan, B. Goodison, P. Crill, K.J. Ranson, D. Lettenmaier, and D.E. Wickland. 1995. The boreal ecosystem-atmosphere study (BOREAS): an overview and early results from the 1994 field year. Bulletin of the American Meteorological Society. 76(9):1549-1577.

Sellers, P.J., F.G. Hall, R.D. Kelly, A. Black, D. Baldocchi, J. Berry, M. Ryan, K.J. Ranson, P.M. Crill, D.P. Lettenmaier, H. Margolis, J. Cihlar, J. Newcomer, D. Fitzjarrald, P.G. Jarvis, S.T. Gower, D. Halliwell, D. Williams, B. Goodison, D.E. Wickland, and F.E. Guertin. 1997. BOREAS in 1997: Experiment Overview, Scientific Results and Future Directions. Journal of Geophysical Research 102(D24): 28,731-28,770.

Striegl, R.G. and K.P. Wickland. 1998. Effects of a clear-cut harvest on soil respiration in a jack-pine lichen woodland. Can. Jour. Forest Research 28:534-539.

Wickland, K.P. and R.G. Striegl. 1997. Measurements of soil carbon dioxide and methane concentrations and fluxes, and soil properties at four ages of jack pine forest in the Southern Study Area of the Boreal Ecosystem Atmosphere Study, Saskatchewan, Canada, 1993-1995. U.S. Geological Survey Open-File Report. 97-49.

\subsection{Archive/DBMS Usage Documentation \\ None.}

\section{Glossary of Terms}

None. 


\section{List of Acronyms}

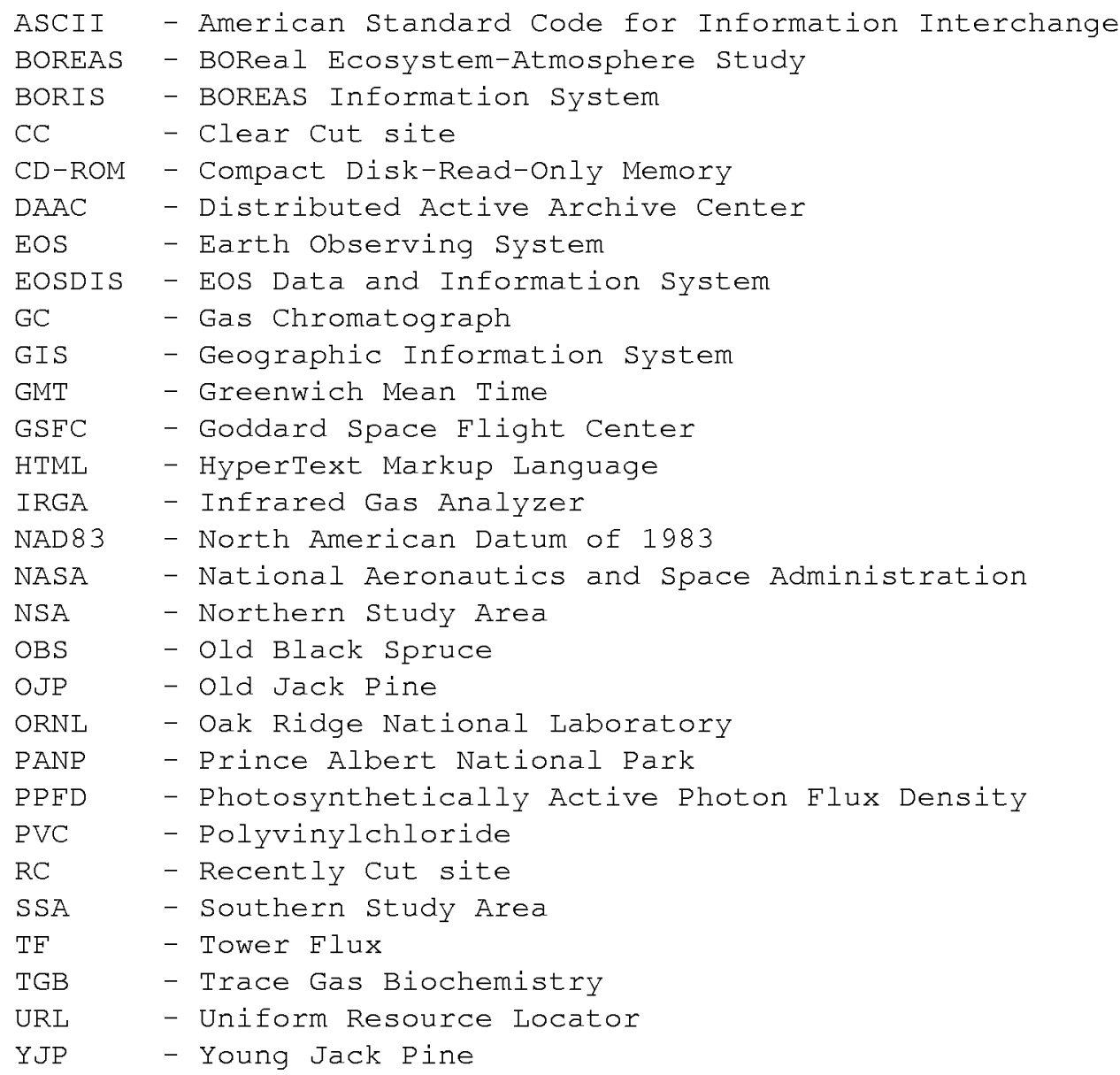

\section{Document Information}

\subsection{Document Revision Date}

Written: 01-Dec-1998

Last Updated: 20-Aug-1999

\subsection{Document Review Date(s)}

BORIS Review: 03-Dec-1998

Science Review:

\subsection{Document ID}




\subsection{Citation}

When using these data, please include the following acknowledgment as well as citations of relevant papers in Section 17.2:

Wickland, K.P., and R.G. Striegl. 1997. Measurements of soil carbon dioxide and methane concentrations and fluxes, and soil properties at four ages of jack pine forest in the Southern Study Area of the Boreal Ecosystem Atmosphere Study, Saskatchewan, Canada, 1993-1995. U.S. Geological Survey Open-File Report. 97-49.

Striegl, R.G. and K.P. Wickland. 1998. Effects of a clear-cut harvest on soil respiration in a jack-pine lichen woodland. Can. Jour. Forest Research 28:534-539.

If using data from the BOREAS CD-ROM series, also reference the data as:

Striegl, R. and K. Wickland, "Automated Measurements of $\mathrm{CO}_{2}$ Exchange at the Moss Surface of a Black Spruce Forest." In Collected Data of The Boreal Ecosystem-Atmosphere Study. Eds. J. Newcomer, D. Landis, S. Conrad, S. Curd, K. Huemmrich, D. Knapp, A. Morrell, J. Nickeson, A. Papagno, D. Rinker, R. Strub, T. Twine, F. Hall, and P. Sellers. CD-ROM. NASA, 2000.

Also, cite the BOREAS CD-ROM set as:

Newcomer, J., D. Landis, S. Conrad, S. Curd, K. Huemmrich, D. Knapp, A. Morrell, J. Nickeson, A. Papagno, D. Rinker, R. Strub, T. Twine, F. Hall, and P. Sellers, eds. Collected Data of The Boreal Ecosystem-Atmosphere Study. NASA. CD-ROM. NASA, 2000.

\subsection{Document Curator}

\subsection{Document URL}


Public reporting burden for this collection of information is estimated to average 1 hour per response, including the time for reviewing instructions, searching existing data sources, gathering and maintaining the data needed, and completing and reviewing the collection of information. Send comments regarding this burden estimate or any other aspect of this collection of information including suggestions for reducing this burden, to Washington Headquarters Services, Directorate for Information Operations and Reports, 1215 Jefferson Davis Highway, Suite 1204, Arlington, VA 22202-4302, and to the Office of Management and Budget, Paperwork Reduction Project (0704-0188), Washington, DC 20503.

\begin{tabular}{|l|l|l|}
\hline 1. AGENCY USE ONLY (Leave blank) & 2. REPORT DATE & 3. REPORT TYPE AND DATES COVERED
\end{tabular}

\begin{tabular}{l|l|l} 
October 2000 & Technical Memorandum
\end{tabular}

4. TITLE AND SUBTITLE

Technical Report Series on the Boreal Ecosystem-Atmosphere Study (BOREAS)

BOREAS TF-4 $\mathrm{CO}_{2}$ and $\mathrm{CH}_{4}$ Chamber Flux Data from the SSA

\section{AUTHOR(S)}

Dean Anderson, Robert Striegl and Kimberly Wickland

Forrest G. Hall and Sara Conrad, Editors

\section{PERFORMING ORGANIZATION NAME(S) AND ADDRESS (ES)}

Goddard Space Flight Center

Greenbelt, Maryland 20771

5. FUNDING NUMBERS

923

RTOP: 923-462-33-01

9. SPONSORING / MONITORING AGENCY NAME(S) AND ADDRESS (ES)

10. SPONSORING / MONITORING AGENCY REPORT NUMBER

National Aeronautics and Space Administration

Washington, DC 20546-0001

TM-2000-209891

Vol. 198

\section{SUPPLEMENTARY NOTES}

D. Anderson, R. Striegl, and K. Wickland: U.S. Geological Survey, Denver; S. Conrad: DynCorp.

\begin{tabular}{l|l}
\hline 12a. DISTRIBUTION / AVAILABILITY STATEMENT & 12b. DISTRIBUTION CODE \\
Unclassified-Unlimited & \\
Subject Category: 43 & \\
Report available from the NASA Center for AeroSpace Information, \\
7121 Standard Drive, Hanover, MD 21076-1320. (301) $621-0390$.
\end{tabular}

13. ABSTRACT (Maximum 200 words)

The BOREAS TF-4 team measured fluxes of $\mathrm{CO}_{2}$ and $\mathrm{CH}_{4}$ across the soil-air interface in four ages of jack pine forest at the BOREAS SSA during August 1993 to March 1995. Gross and net flux of $\mathrm{CO}_{2}$ and flux of $\mathrm{CH}_{4}$ between soil and air are presented for 24 chamber sites in mature jack pine forest, 20year-old, 4-year-old, and clear cut areas. The data are stored in tabular ASCII files.

14. SUBJECT TERMS
BOREAS, tower fluX.
\begin{tabular}{l|l} 
17. SECURITY CLASSIFICATION \\
OF REPORT & $\begin{array}{c}\text { 18. SECURITY CLASSIFICATION } \\
\text { OF THIS PAGE } \\
\text { Unclassified }\end{array}$ \\
Unclassified
\end{tabular}

19. SECURITY CLASSIFICATION OF ABSTRACT

Unclassified
15. NUMBER OF PAGES

18

16. PRICE CODE

\section{LIMITATION OF ABSTRACT}

UL 
